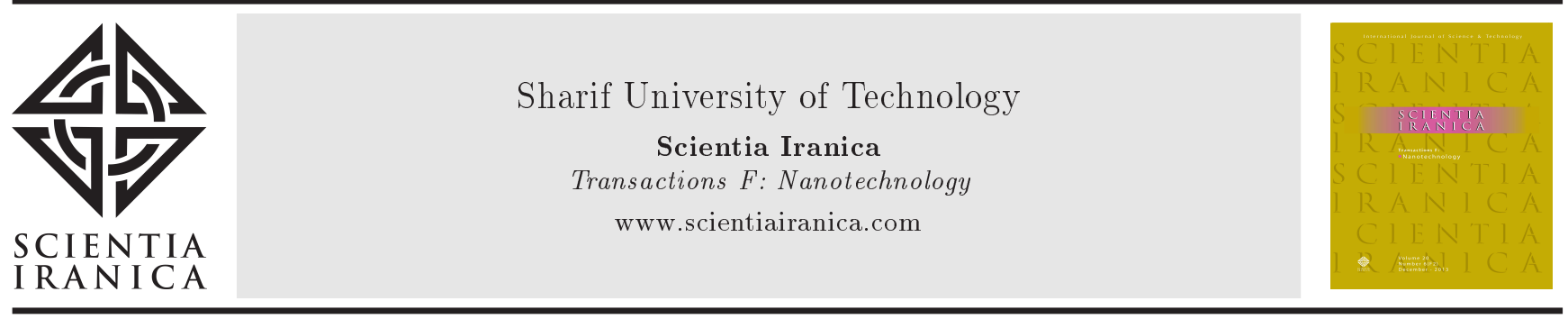

Research Note

\title{
Copper-doped and copper-free bioactive glass nanopowders cytotoxicity and antibacterial activity assessment
}

\author{
Sh. Soltani-Dehnavi ${ }^{a}$, M. Mehdikhani-Nahrkhalaji ${ }^{b, *}$, M. Rafienia ${ }^{c}$ and \\ A. Doostmohammadid \\ a. Department of New Science and Technology Campus (Biomaterial Group), Semnan University, Semnan, P.O. Box 35131-19111, \\ Iran. \\ b. Department of Biomedical Engineering, Faculty of Engineering, University of Isfahan, Isfahan, P.O. Box 81746-13441, Iran. \\ c. Biosensor Research Center, Isfahan University of Medical Sciences, Isfahan, Iran. \\ d. Department of Materials, Faculty of Engineering, Shahrekord University, Shahrekord, Iran.
}

Received 29 February 2016; received in revised form 16 August 2016; accepted 10 December 2016

\section{KEYWORDS \\ Bioactive glass nanopowders; \\ Sol-gel technique; \\ Antibacterial \\ properties; \\ Cytotoxicity; \\ Sol-gel technique.}

\begin{abstract}
The purpose of this study is to evaluate the antibacterial activity and cytotoxicity of copper-doped (Cu45SBG) and copper-free bioactive glass (45SBG) nanopowders. The antibacterial effect was studied using Escherichia coli (E. coli) and Staphylococcus aureus (S. aureus) bacteria. The BG nanopowders were synthesized by the sol-gel technique. They were characterized by various techniques and their cytotoxicity was evaluated by MTT assay. Chemical compositions of BGs were as the same as the predicted compositions. The size of the BGs with an amorphous structure was measured to be around $100 \mathrm{~nm}$. Both BG nanopowders have no antibacterial effect on broth concentrations less than $12.5 \mathrm{mg} / \mathrm{ml}$. They demonstrated similar antibacterial activity on E. coli with Minimum Bactericidal Concentration (MBC) of $12.5 \mathrm{mg} / \mathrm{ml}$. Cu45SBG nanopowders with the $\mathrm{MBC}$ of $25 \mathrm{mg} / \mathrm{ml}$ were more efficient on $S$. aureous bacteria than $45 \mathrm{SBG}$ nanopowders with the MBC of $50 \mathrm{mg} / \mathrm{ml}$. Compared to 45SBG, Cu45SBG showed much more cytotoxicity. 45SBG demonstrated similar cells viability to the control. It was concluded that to overcome cytotoxic effect, Cu content of BGs nanopowders must be lower than the amount used in this research. Therefore, 45SBG nanopowders with considerable antibacterial activity could be used as a good candidate for biomedical applications.
\end{abstract}

(C) 2017 Sharif University of Technology. All rights reserved.

\section{Introduction}

The most important elaborations caused by biomaterials are infections and lack of tissue integrity. The treatment of these infections is so complicated for both

*. Corresponding author. Tel.: +983137934515;

Fax: +98 31379327r1

E-mail addresses: soltani1222@yahoo.com (Sh.

Soltani-Dehnavi); m.mehdikhani@eng.ui.ac.ir (M.

Mehdikhani-Nahrkhalaji); m_rafienia@med.mui.ac.ir (M.

Rafienia); Alidstm@gmail.com (A. Doostmohammadi) of healthcare system and patients due to increased morbidity and mortality, long stay in hospital, and grave costs $[1,2]$. Bacteria, based on different membrane structures, can be divided into two broad categories: gram-negative and gram-positive bacteria [3]. The most important bacteria are between the gram-positive ( $S$. aureus) and the gram-negative bacteria ( $E$. coli) causing orthopedic and maxillofacial infections $[4,5]$. Biomaterials with antibacterial activity play a major role in modern dental and medical sciences, such as the replacement of organs and tissues, in order to 
improve their functions [6]. BGs, in the ternary system, have shown rapid formation of carbonate substituted hydroxyapatite-like (HCA) layer in Simulated Body Fluid (SBF) [7-13]. BGs are more bioactive than calcium phosphate compounds; in addition, the silicabased BGs bioactivity reactions are faster than hydroxyapatite (HA). One of the most important characteristics of BGs is that they can provide an ideal environment for genetic control and stimulation of human osteoblasts to be proliferated and differentiated as they lead to bone formation both in vitro and in vivo with rapid bone regeneration $[1,14,15]$. There are two processing methods for synthesizing BGs: traditional melt quenching and versatile sol-gel methods. Between them, due to producing small glass particles with a high-surface area, increased resorption rate, and higher bioactivity, the sol-gel method is more attractive than the other $[6,16,17]$. Some of certain BGs have also shown the antibacterial effect [1,18]. For instance, particulate Bioglass ${ }^{\circledR}$ is one of the materials which displays significant antibacterial effect on certain oral bacteria [19]. Recently, the S53P4BG and some other sol-gel derived BGs have also shown antibacterial activity on a wide selection of clinically important aerobic bacteria [20,21]. In recent studies, Mortazavi et al. [1] showed that $58 \mathrm{~S}$ and $63 \mathrm{~S}$ BG nanopowders have antibacterial effect on the studied aerobic bacteria with the MBCs of 50 and $100 \mathrm{mg} / \mathrm{ml}$ depending on the studied aerobic bacteria. They showed that the 58SBG nanopowders have a stronger bactericidal activity compared to the $63 \mathrm{SBG}$ nanopowders. Studies demonstrated that material properties, including active surface area, chemical reactivity, biological activity, electrical conductivity, and hardness, could be changed by decreasing particles size from a micrometer to a nanometer. A very important issue of these different properties is antimicrobial effect of metals nanopowders such as silver, copper, titanium, and zinc. Indeed, both small-sized particle and high surface-to-volume ratio can affect bactericidal activity of metal nanopowders. Therefore, nanopowders have a better and closer interaction with bacterial membranes, which is related to the metal ion release in solution [3,20,22-25]. Silver, copper, and Zinc ( $\mathrm{Ag}, \mathrm{Cu}$, and $\mathrm{Zn})$, especially in the form of free ions, are widely known to display strong antibacterial effects and preventive activities on different bacteria. In addition, these metal ions, in terms of durability of antibacterial effects and resistance to heat and safety, are superior to organic antibacterial agents. However, These metals are unstable in their ionic states and may have toxic effects if they are swallowed directly. One important achievement to overcome these problems is to connect metal ions to the substrate as a supporting materials, such as hydroxyapatite (HAp), zeolites, silica, bioglass, and carbon fibers, so that the stability of ionic states can be recovered and metal ions delivered during a long period of time [26]. The objective of the present investigation is to evaluate cytotoxicity and antibacterial activity of $\mathrm{Cu} 45 \mathrm{SBG}$ and $45 \mathrm{SBG}$ nanopowders against $E$. coli and $S$. aureus bacteria to determine the Minimum Bactericidal Concentration (MBC).

\section{Materials and methods}

\subsection{Glass synthesis}

The $45 \mathrm{~S}$ sol-gel glass with a glass composition of $\mathrm{SiO}_{2}$ $\mathrm{P}_{2} \mathrm{O}_{5}-\mathrm{CaO}\left(44.5 \mathrm{~mol} \% \mathrm{SiO}_{2}, 48.1 \mathrm{~mol} \% \mathrm{CaO}\right.$, and $3.5 \mathrm{~mol} \% \mathrm{P}_{2} \mathrm{O}_{5}$ ) was synthesized by the following steps. The starting materials for preparing BG nanopowders included deionized water, tetraethoxysilane (TEOS; Merck), triethyl phosphate (TEP; Merck), calcium nitrate tetrahydrate (Merck), ethanol, copper nitrate (Merck), and 2N hydrochloric acid. Initially, the proper amounts of TEOS $(15.6 \mathrm{ml})$ and ethanol $(50 \mathrm{ml})$ as an alcoholic media with $2 \mathrm{~N}$ hydrochloric acid $(2.5 \mathrm{ml})$ and deionized water $(15 \mathrm{ml})$ were mixed together and stirred at room temperature for $30 \mathrm{~min}$ until the mixture became transparent. The volume ratio of ethanol:TEOS was $3: 1$. Then, TEP $(0.5 \mathrm{ml})$ was added to the solution and stirred for another $20 \mathrm{~min}$. At the end, calcium nitrate $(19.8 \mathrm{~g})$ was added to the solution. Then, the solution was stirred for an additional hour. The gel was transferred into a sealed Teflon container for ageing process, then heated for $52 \mathrm{~h}$ at $60^{\circ} \mathrm{C}$, and dried for $48 \mathrm{~h}$ at $130^{\circ} \mathrm{C}$. Finally, the dried samples were calcined for $1 \mathrm{~h}$ at $600^{\circ} \mathrm{C}$. The prepared specimens were ground with a mortar and pestle to prevent agglomeration of nanopowders, and then sieved to produce a particle size less than $180 \mathrm{~nm}$. Cu45SBG nanopowders, $\mathrm{SiO}_{2}-\mathrm{P}_{2} \mathrm{O}_{5}-\mathrm{CaO}-$ $\mathrm{CuO}\left(44.7 \mathrm{~mol} \% \mathrm{SiO}_{2}, 45.51 \mathrm{~mol} \% \mathrm{CaO}, 3.95 \mathrm{~mol} \%\right.$ $\mathrm{P}_{2} \mathrm{O}_{5}$, and $1.311 \mathrm{~mol} \% \mathrm{CuO}$ ), were synthesized by adding copper nitrate $(0.38 \mathrm{~g})$ to the solution after the addition of calcium nitrate to compare its bactericidal behavior with the 45SBG nanopowders.

\subsection{Characterization of BGs}

Field Emission Scanning Electron Microscopy (FESEM) (S4160, HITACHI, Japan), Transmission Electron Microscopy (TEM) (CM120-Philips), and Zetasizer (Cordouan- VASCO Particle size analyzer) were used to determine and study the surface, morphology, and particle size distribution of $B G$ nanopowders. X-Ray Diffraction (XRD) technique (D8-ADVANCE Brüker system with a $\mathrm{Cu} \mathrm{Ka}(\lambda=0.15406 \mathrm{~nm})$ using $\mathrm{Ni}$ filtered) was used to characterize the crystallinity and phases present in BG nanopowders. The diffractometer was operated at $35 \mathrm{kV}$ and $30 \mathrm{~mA}$ over the range of $10.000-90.015$ and a step size of $0.065^{\circ} / \mathrm{S}$. XRay Fluorescence (XRF) spectroscopy (S4PIONEER, BRUKER, Germany) and energy dispersive X-ray anal- 
ysis (EDX) technique (ZEISS, Germany) emphasized the elemental composition of BGs.

\subsection{Antibacterial activity}

BG nanopowders at 100, 50, 25, 12.5, and $6.25 \mathrm{mg} / \mathrm{ml}$ concentrations of broth were used to evaluate the Minimal Bactericidal Concentration (MBC) of particles leading to a $99.9 \%$ decline in viability of the bacteria. To specify the MBC of each BG nanoparticle, the bacterial broth dilution method documented in National Committee for Clinical Laboratory Standards publication, M7-T2, was used as a bacterial susceptibility test [1]. For comparison, 45SBG and Cu45SBG nanopowders were tested. Gram-negative bacteria Escherichia Coli (E. coli, ATCC 25922) as well as a gram-positive bacteria Staphylococcus aureus ( $S$. aureus, ATCC 25923) were used for investigating the antibacterial activities. Tryptone Soya Broth (TSB, OXOID, England, and CM129) was used as the culture media. At the first step, two strains were grown in a TSB medium, and then incubated for $24 \mathrm{~h}$ at $37^{\circ} \mathrm{C}$. The suspensions of nanopowders in TSB were prepared, and incubation was done in a shaking incubator for better ion delivering. Then, the standard inoculums of the microorganisms $\left(1.5 \times 10^{7}\right.$ bacteria $\left./ \mathrm{ml}\right)$, according to $0.5 \mathrm{McFarland}$ standard in 0.01 dilution, were added to the suspension containing nanopowders with different concentrations $(100,50,25,12.5$, and $6.25 \mathrm{mg} / \mathrm{ml})$. After that, incubation was done in a shaking incubator $\left(250 \mathrm{rpm}\right.$ at $37^{\circ} \mathrm{C}$ in air for $\left.24 \mathrm{~h}\right)$. After 24, 48, and $72 \mathrm{~h}, 0.1 \mathrm{ml}$ of the suspensions containing BG nanopowders were cultured on nutrient agar (NUTRIENT AGAR, OXOID, England, and CM3) plates. For each experimental time after cultivation for $24 \mathrm{~h}$, the number of colonies emerged on the plates was counted. Bacterial cultures without BG nanopowders were used as negative controls. The bactericidal effect of each tube was carried out in triplicate. Lack of growth of the nutrient agar plates (0) was an illustrator of bactericidal effect of BG nanopowders. The growing inhibitory effect of nanopowders was demonstrated by very sparse, sparse, and average growths (1, 2, and 3 , respectively). Good growth (4) of bacteria on nutrient agar plates indicated that nanopowders have no bactericidal effect. $\mathrm{PH}$ changes of the suspensions containing BG nanopowders in TSB without bacteria were measured at each interval.

\subsection{Cytotoxicity evaluation of the prepared BGs}

Mouse fibroblast L929 cell line, cell bank code C161, was obtained from the Pasteur Institute of Iran (Tehran). Cells were cultured in Dulbecco's Modified Eagle Medium supplemented with $10 \%$ fetal bovine serum and $1 \%$ penicillin/streptomycin under standard cell culture conditions (i.e., $37^{\circ} \mathrm{C}$, humidified, $5 \%$
$\mathrm{CO}_{2} / 95 \%$ air environment). After reaching complete confluence, the cells were detached by a $0.25 \%$ solution of trypsin-ethylenediaminetetraaceticacid (EDTA) to be then subcultured in Dulbecco's Modified Eagle Medium. During the subculturing process, the medium was replaced every 3 days. Before the experiments, cells were lifted from tissue culture flasks using a trypsin-containing solution, counted, and added at a density of $4 \times 10^{4}$ to the 24 -well plates; after $2 \mathrm{~h}$, the medium was changed to one containing ionic products from the dissolution of bioactive glass nanopowders. The culture without extracts was used as control. Extracts for indirect tests were obtained from the materials under standardized conditions (ISO 10993-5). The 3-(4, 5-dimethylthiazol-2-yl)-2, 5-diphenyl tetrazolium bromide (MTT) assay was used in this study to measure cell vitality and proliferation. The MTT agent reacts with the tetrazolium ring to produce blue formazan crystals. At 1, 4, and 7 days, the supernatant was removed from the wells, and the cells were rinsed three times with phosphate-buffered saline to eliminate nonviable cells. Twenty microliters per well of the MTT solution ( $5 \mathrm{mg} / \mathrm{mL}$ in phosphate-buffered saline) were added, and the cells were incubated at $37^{\circ} \mathrm{C}$ for $4 \mathrm{~h}$ to allow the formation of formazan crystals. After incubation, the supernatant was removed, and $150 \mu$ l dimethyl sulfoxide was then added to each well to dissolve the formazan crystals under shaking. The absorbance was read on Micro Elisa reader (Hyperion, Florida) using a test wavelength of $540 \mathrm{~nm}$. The results from three individual experiments were averaged and reported as optical density values. The results were statistically analyzed using analysis of variance. A $p$ value less than 0.05 was considered as statistically significant.

\subsection{Dissolution kinetics of the $B G s$}

This method was exerted in order to determine the ionic dissolution species released from the particles into the culture medium as a factor which can be effective in growth of bacterial colonies. For this purpose, sample's suspensions were prepared in the absence of bacteria in TSB medium with the same experimental conditions as those of the bacterial tests. After 0$120 \mathrm{~h}$, suspensions free from nanopowders were filtered using a sterile filtration (GVS, SINGELE USE FILTER UNIT, $0.20 \mu \mathrm{m}$, USA), and then transferred into the sterile falcons. Finally, $\mathrm{Ca}, \mathrm{p}$, and $\mathrm{Cu}$ concentrations of the medium containing nanopowders were measured by atomic absorption spectrophotometer (AES) (PERKINELMER400, USA). The evaluation of invitro bioactivity was also performed via soaking the powders in Kokubo's SBF. Estimating the rate of dissolution of network forming silica species from $\mathrm{Cu} 45 \mathrm{SBG}$ and $45 \mathrm{SBG}$ was the purpose of this study. The ratio of nanopowders to the solution was considered $1 \mathrm{mg} / \mathrm{ml}$. All the samples were incubated at $37^{\circ} \mathrm{C}$ 
for various time periods such as $0,24,48,72,96$, and $120 \mathrm{~h}$. At each interval, $50 \mathrm{mg}$ concentrations of both powders were used. During various immersion times (0-120 h), the dissolution of $\mathrm{Ca}, \mathrm{P}$, and $\mathrm{Cu}$ ions into the Simulated Body Fluid (SBF) was measured by using the inductively coupled plasma optical emission spectrometry (ICP-OES) analysis (OPTIMA 7300 DVPERKINELMER, USA).

\section{Results}

\subsection{Characterization of $B G s$}

Figures 1, 2, and 3 illustrate TEM, FESEM images, and particle-size distribution measured by Zetasizer of the prepared BG nanopowders. According to the results, the size of the nanopowders was obtained mainly around $100 \mathrm{~nm}$ and contained a wide range of shapes from spherical to irregular configuration. In FESEM images, heterogeneous nanopowders can be observed in various sizes. According to TEM and FESEM images, the prepared BG nanopowders formed some agglomerations which are due to the high-

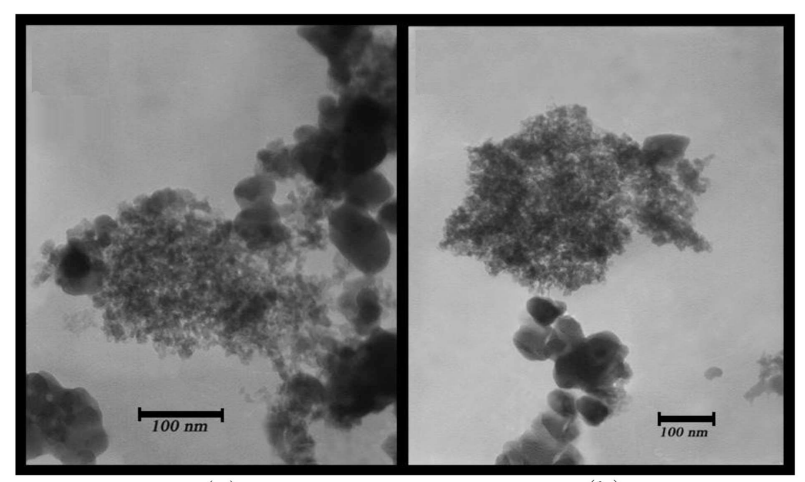

(a)

(b)

Figure 1. TEM images of (a) $45 \mathrm{SBG}$ and (b) Cu45SBG nanopowders.

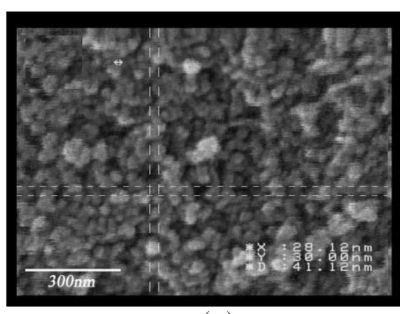

(a)

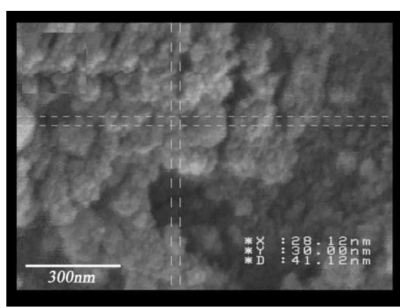

(c)

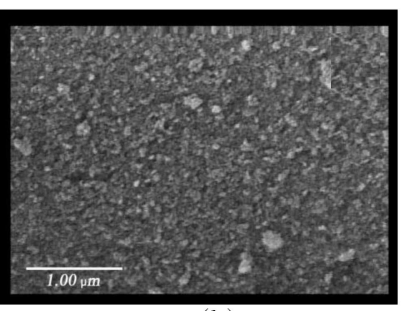

(b)

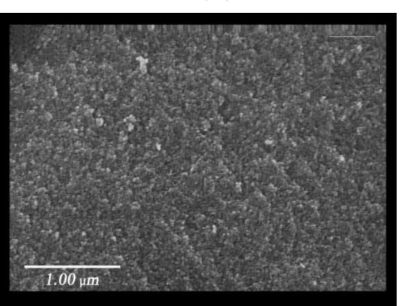

(d)
Figure 2. FESEM images of (a, b) 45SBG and (c, d) Cu45SBG nanopowders. surface area of them. The XRD patterns approve the formation of the BG nanopowders with amorphous structure (Figure 4). According to the XRF analysis results, the synthesized BG nanopowders compositions were the same as predicted ones (Table 1). The results of quantitative EDX analysis spectrum are shown in Figure 5. It can be seen that the peaks of $\mathrm{Si}, \mathrm{Ca}, \mathrm{P}$, and $\mathrm{Cu}$ confirm and indicate the presence of all the introduced elements of the prepared BG nanopowders.

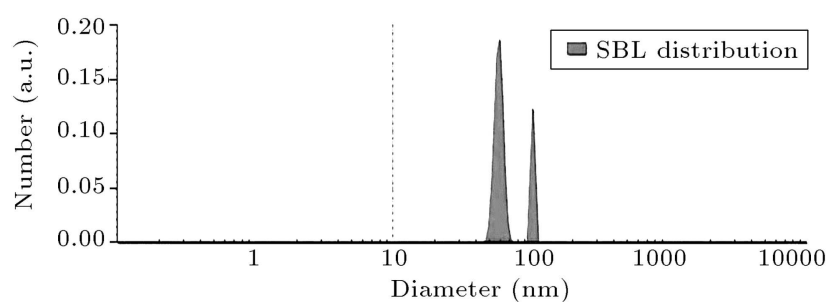

(a)

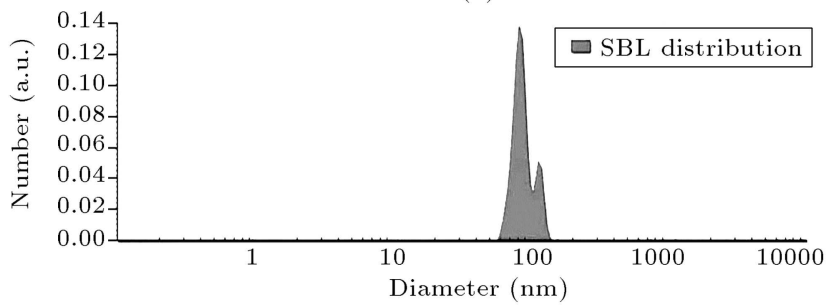

(b)

Figure 3. Particle size distribution of the BG nanopowders: (a) $45 \mathrm{SBG}, 38.28-99.77 \mathrm{~nm}$, polydispersity $=0.06162$ and $Z$-average $=95.45$, and (b) Cu45SBG, $33.55-106.33 \mathrm{~nm}$, polydispersity $=0.07989$ and $Z$-average $=101.06$.

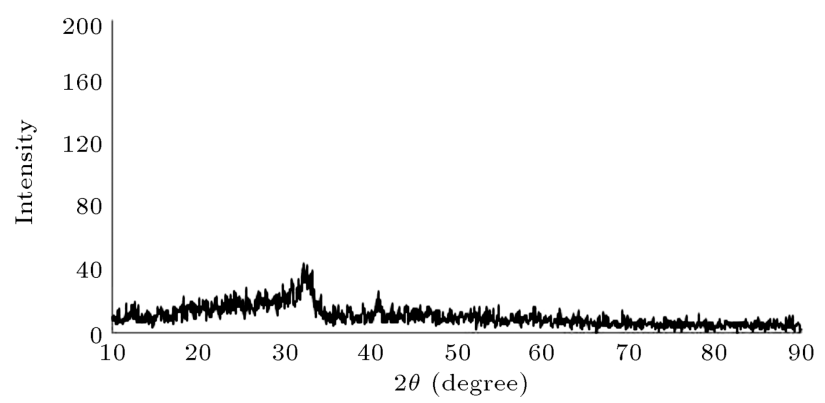

(a)

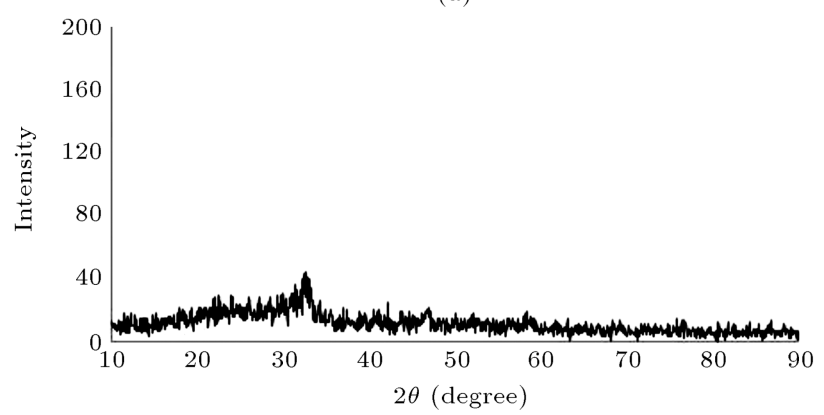

(b)

Figure 4. XRD patterns of (a) 45SBG and (b) Cu45SBG nanopowders. 


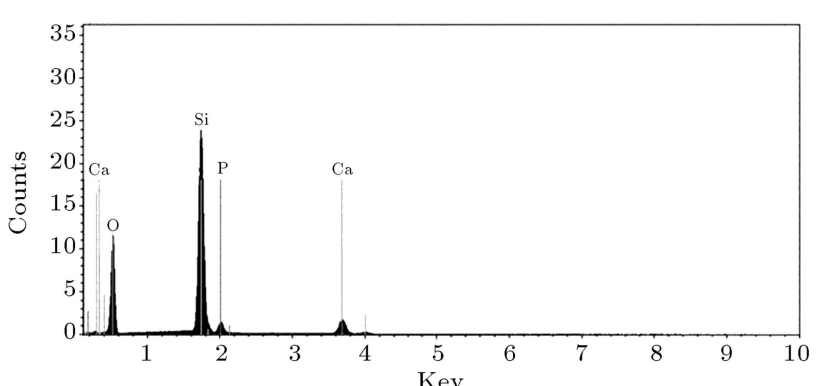

(a)

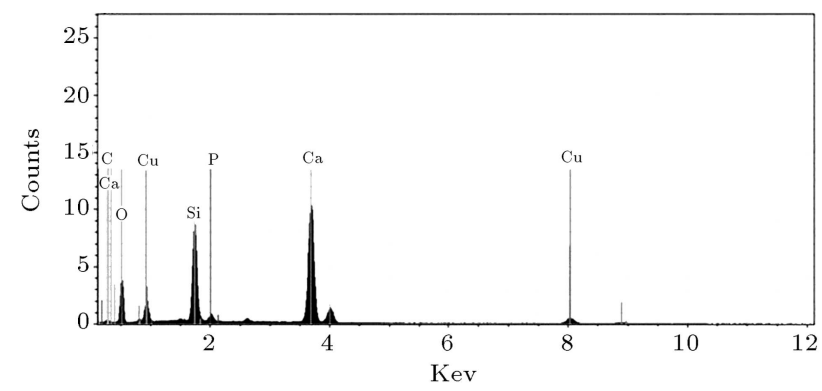

(b)

Figure 5. Quantitative EDS spectrum of (a) 45SBG and (b) Cu45SBG samples.

\subsection{Antibacterial activity}

For both BGs in broth concentrations lower than $12.5 \mathrm{mg} / \mathrm{ml}$, the $\mathrm{BG}$ nanopowders demonstrated no antibacterial effect on $E$. coli and $S$. aureus bacteria,
Table 1. Chemical compositions of two types of bioactive glass nanopowders (weight ratio \%).

\begin{tabular}{lcccc}
\hline Composition & $\mathrm{SiO}_{\mathbf{2}}$ & $\mathbf{C a O}$ & $\mathbf{P}_{\mathbf{2}} \mathbf{O}_{\mathbf{5}}$ & $\mathbf{C u O}$ \\
\hline $\mathrm{Cu} 45 \mathrm{SBG}$ & 44.7 & 45.51 & 3.96 & 1.311 \\
$45 \mathrm{SBG}$ & 44.5 & 48.1 & 3.5 & \\
\hline
\end{tabular}

and they showed the same behavior as the control. Figure 6 shows the antibacterial activity of $\mathrm{Cu} 45 \mathrm{SBG}$ and 45SBG nanopowders at broth concentrations of $100,50,25,12.5$, and $6.25 \mathrm{mg} / \mathrm{ml}$ on E. coli (Figure 6(a) and (b)) and S. aureus (Figure 6(c) and (d)), respectively. At the concentrations of 100, 50, 25 , and $12.5 \mathrm{mg} / \mathrm{ml}$, both $\mathrm{BG}$ nanopowders showed similar bactericidal effects on E. coli. Their MBC was recorded at $12.5 \mathrm{mg} / \mathrm{ml}$ for $E$. coli. Cu45SBG nanopowders had no bactericidal activity on $S$. aureus at the concentrations below $25 \mathrm{mg} / \mathrm{ml}$, and its $\mathrm{MBC}$ was considered $25 \mathrm{mg} / \mathrm{ml}$. Concentrations less than $50 \mathrm{mg} / \mathrm{ml}$ illustrated no antibacterial effects on $S$. aureus by $45 \mathrm{SBG}$ nanopowders. So, the MBC value of $45 \mathrm{SBG}$ nanopowders was measured $50 \mathrm{mg} / \mathrm{ml}$. On S. aureus bacteria, $\mathrm{Cu} 45 \mathrm{SBG}$ nanopowder was more effective than 45SBG nanopowder (Figure 7). Figure 8 demonstrates the $\mathrm{pH}$ changes in the tryptone soya broth containing both BGs. The primary $\mathrm{pH}$ of the TSB media was 7.3. The broth containing 45SBG

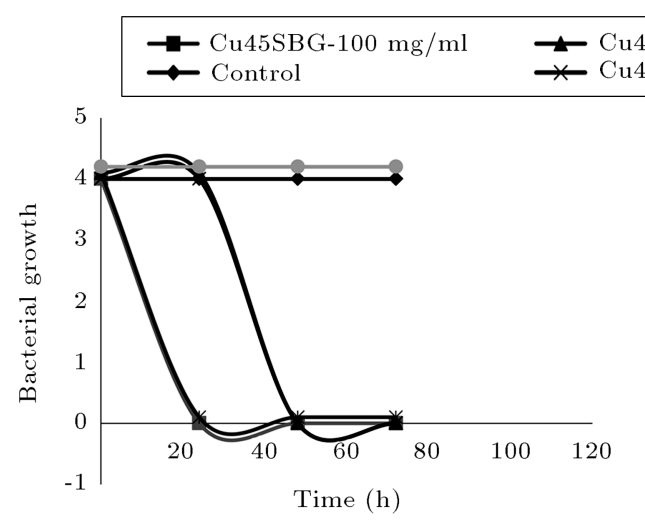

(a)

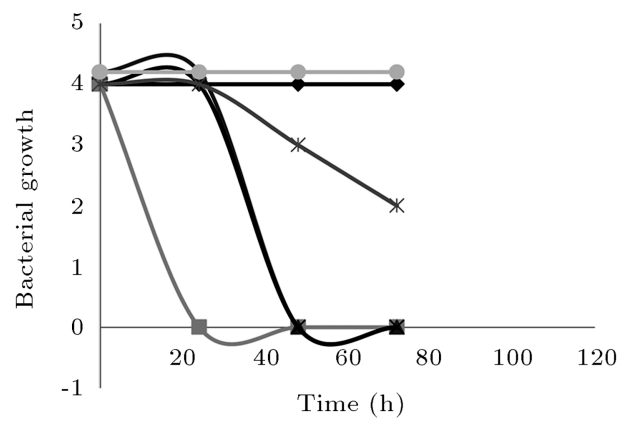

(c)

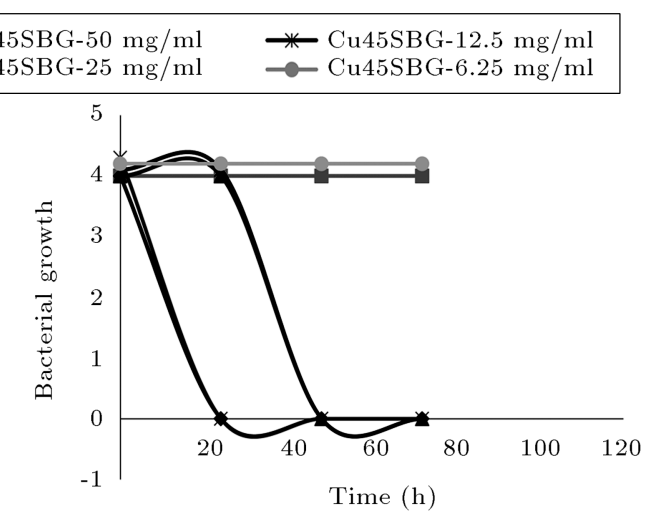

(b)

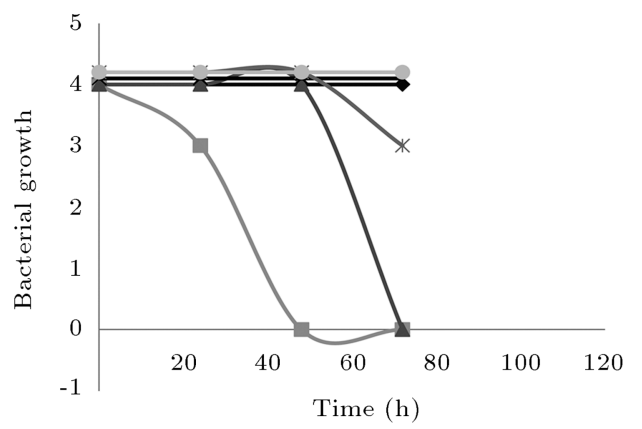

(d)

Figure 6. Effects of Cu45SBG and 45SBG nanopowders on the growth of E. coli (a, b) and S. aureus (c, d) at a concentration of $100,50,25,12.5$, and $6.25 \mathrm{mg} / \mathrm{ml}$ of broth. On the bacterial growth axis of the figure, 4 represents good growth (positive control), 3 moderate growth, 2 sparse growth, 1 very sparse growth, and 0 no growth. 


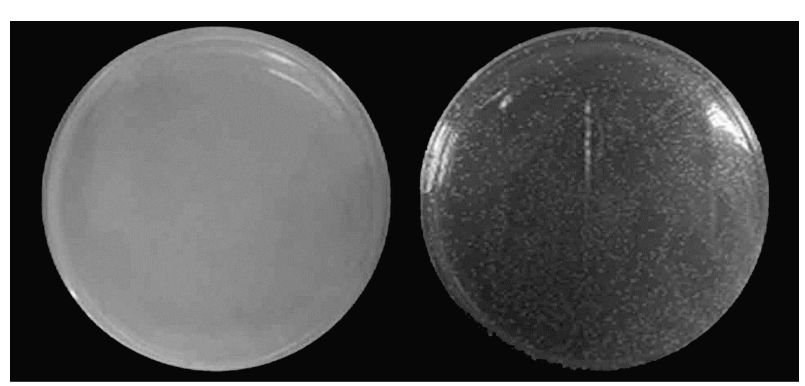

(a)

(b)

Figure 7. Representative photo of bactericidal action of (a) Cu45SBG and (b) 45SBG on S. aureusin; the culture medium contains $25 \mathrm{mg} / \mathrm{ml}$ of BG material after $72 \mathrm{~h}$ exposure.

and $\mathrm{Cu} 45 \mathrm{SBG}$ nanopowders displayed a considerable $\mathrm{pH}$ rise. After $48 \mathrm{~h}$, for 100, 50, 25, 12.5, and $6.25 \mathrm{mg} / \mathrm{ml}$ concentrations, $\mathrm{pH}$ rose to above 9.5 . At this time, the highest $\mathrm{pH}$ level was reported at 11.8 for the $100 \mathrm{mg} / \mathrm{ml}$ concentration of the samples. These increases always were higher for $45 \mathrm{SBG}$ than $\mathrm{Cu} 45 \mathrm{SBG}$ nanopowders. After $48 \mathrm{~h}$, up to $72 \mathrm{~h}$, pH slightly decreased for both BGs at all concentrations except $6.25 \mathrm{mg} / \mathrm{ml}$ concentration for $45 \mathrm{SBG}$ nanopowders. Again, $\mathrm{pH}$ decreased for both BGs at all concentrations after $72 \mathrm{~h}$ up to $96 \mathrm{~h}$. Ultimately, after $120 \mathrm{~h}$, $\mathrm{pH}$ slightly increased for Cu45SBG nanopowders at all concentrations except $25 \mathrm{mg} / \mathrm{ml}$. In this time, for 45SBG nanopowders, $\mathrm{pH}$ increased for 50 and $25 \mathrm{mg} / \mathrm{ml}$ concentrations and decreased for 100, 12.5, and $6.25 \mathrm{mg} / \mathrm{ml}$. At each interval, $\mathrm{pH}$ value of nanopowders at all concentrations (except $6.25 \mathrm{mg} / \mathrm{ml}$ concentrations for Cu45SBG nanopowders after 96 and $120 \mathrm{~h}$ ) was greater than the control sample and rose to nearly 12 .

\subsection{Cytotoxicity evaluation of the BGs}

The MTT assay results were shown in Figure 9. After one day of incubation, both the synthesized samples showed significant statistical differences with the control $(p<0.05)$. But, 45SBG demonstrated less

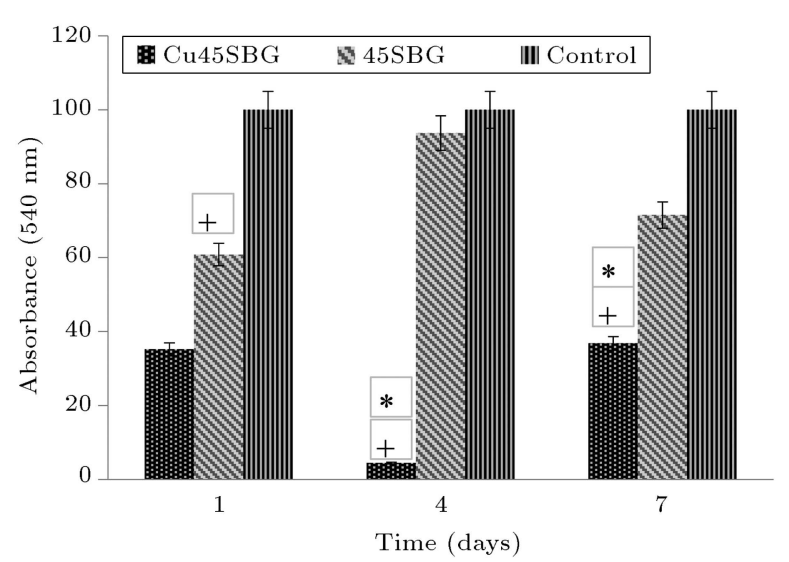

Figure 9. MTT assay results. The absorbance values are proportional to the number of viable cells. The negative control (control-) is the culture medium without extracts. Difference from control: $+p<0.05$ and difference from 45SBG: $* p<0.05$.

cytotoxicity than Cu45SBG $(p<0.05)$. By 4 days, $\mathrm{Cu} 45$ SBG indicated considerable cytotoxic effect on the cultured cells $(p<0.05)$. There was no significant difference between 45SBG and the control. For the samples cultured for 7 days, significant statistical difference was observed between 45SBG and the control and $\mathrm{Cu} 45 \mathrm{SBG}(p<0.05)$. At this time, $45 \mathrm{SBG}$ and the control showed statistical difference $(p<0.05)$.

\subsection{Dissolution kinetics of the BGs}

$\mathrm{Ca}, \mathrm{P}$, and $\mathrm{Cu}$ ionic species concentrations released from the nanopowders into the TSB medium are demonstrated in Figures 10, 11, and 12. After $24 \mathrm{~h}$ immersion, $\mathrm{Ca}$ and $\mathrm{P}$ concentrations in the broth containing 45SBG nanopowders were higher than that for $\mathrm{Cu} 45$ SBG nanopowders. By $120 \mathrm{~h}$, Ca and $\mathrm{P}$ released for $\mathrm{Cu} 45 \mathrm{SBG}$ nanopowders were higher than those for 45SBG nanopowders. Ca concentration in the broth for $\mathrm{Cu} 45 \mathrm{SBG}$ nanopowders at $50 \mathrm{mg} / \mathrm{ml}$ concentration was always higher than that for $45 \mathrm{SBG}$ nanopowders. The highest $\mathrm{Cu}$ concentration in the broth was obtained at $12.5 \mathrm{mg} / \mathrm{ml}$ concentration after $96 \mathrm{~h}$. Figure 13

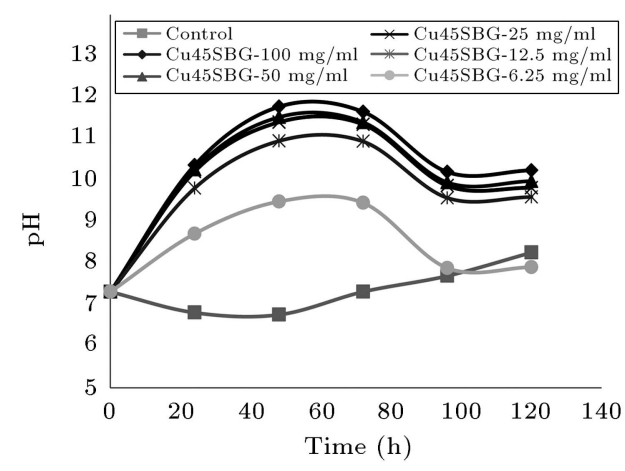

(a)

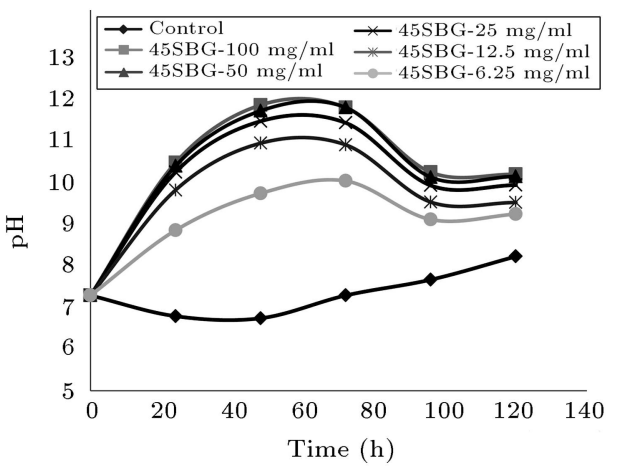

(b)

Figure 8. The pH changes of the broth containing (a) Cu45SBG and (b) 45SBG nanopowders. 


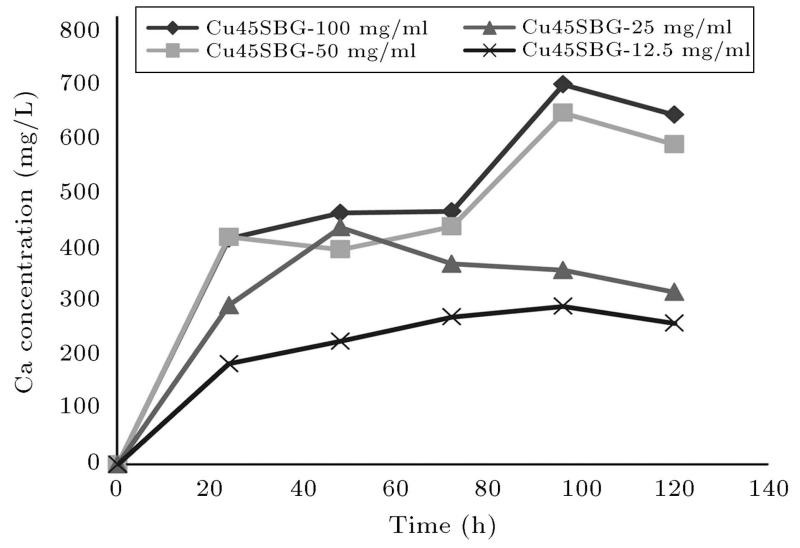

(a)

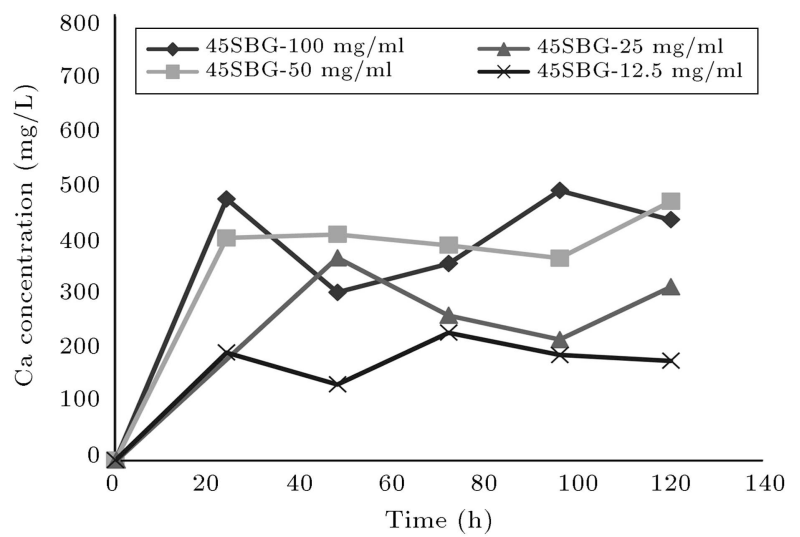

(b)

Figure 10. Calcium concentrations in the broth containing (a) Cu45SBG and (b) 45SBG nanopowders as a function of immersion time in TSB.

shows $\mathrm{Ca}, \mathrm{P}$, and $\mathrm{Cu}$ ionic species concentrations which leached out from the nanopowders into the SBF solution. The initial phosphate concentrations in the SBF solution containing Cu45SBG nanopowders were higher than that for 45SBG nanopowders. Phosphate concentration in the solution significantly decreased during the test time. The concentration of Ca species in the solution steadily increased after the first few hours of the soaking period. Ca concentration in the solution containing 45SBG nanopowders is higher than that for $\mathrm{Cu} 45 \mathrm{SBG}$ nanopowders. $\mathrm{Cu}$ dissolution rate is relatively slow. The increase of $\mathrm{Ca}$ concentration in the SBF solution and the reduction of phosphate ions are indications for the incidence of the surface chemical reaction on the nanopowders surface such as hydroxycarbonate apatite (HCA) layer formation [6].

\section{Discussion}

According to TEM and FESEM images, the prepared BG nanopowders showed some agglomerations which are due to their high-surface area (Figures 1 and 2). The final size of the sol-gel-derived BG nanopowders

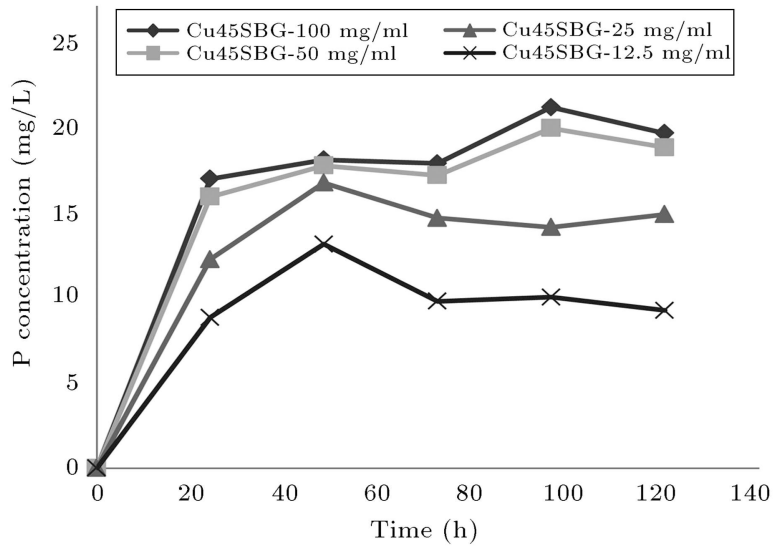

(a)

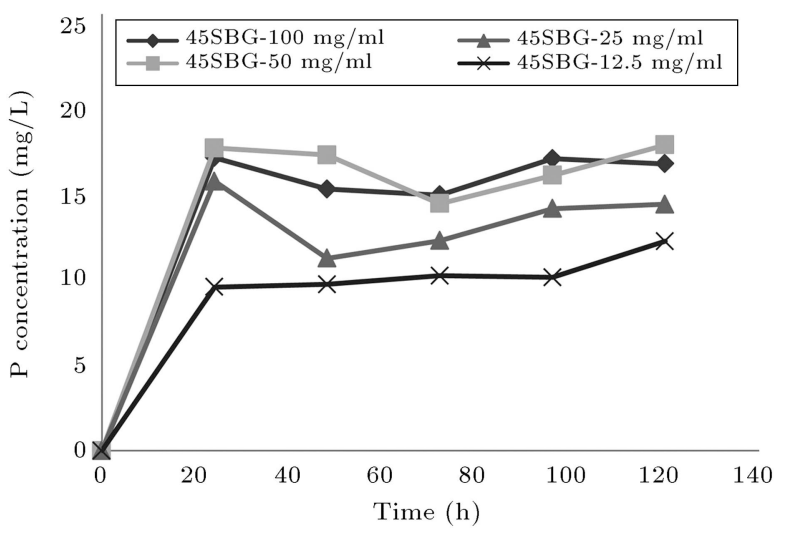

(b)

Figure 11. Phosphorous concentrations in the broth containing (a) Cu45SBG and (b) 45SBG nanopowders as a function of immersion time in TSB.

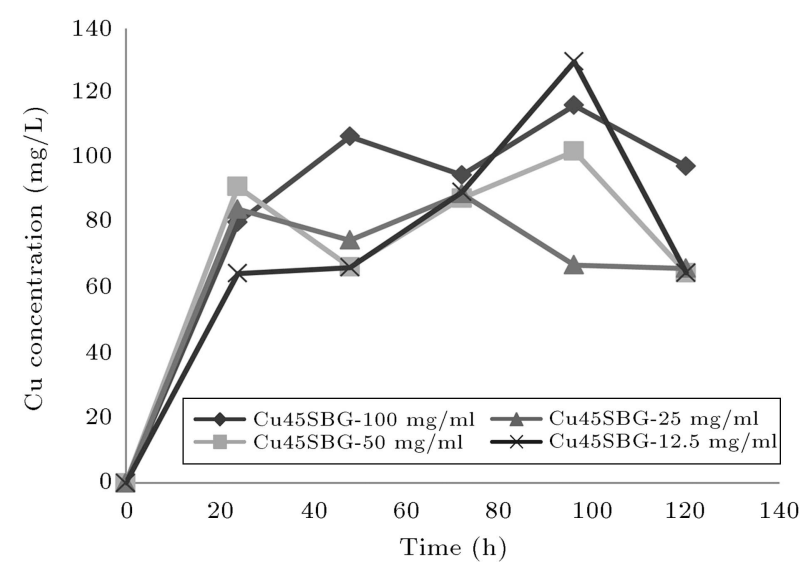

Figure 12. Cu concentration in the broth containing Cu45SBG nanopowders as a function of immersion time in TSB.

depends on many factors, such as alkoxides type (methoxide, ethoxide, penthoxide, etc.), initial concentration of water, and type of alcohol (methanol, ethanol, butanol, and pentanol). The effects of these factors on hydrolysis and polycondensation chemical reactions can greatly specify the size of the sol-gel- 


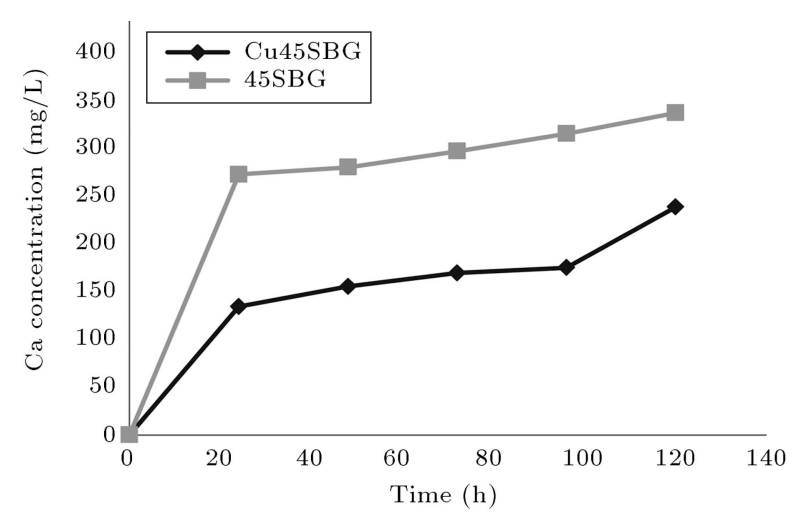

(a)

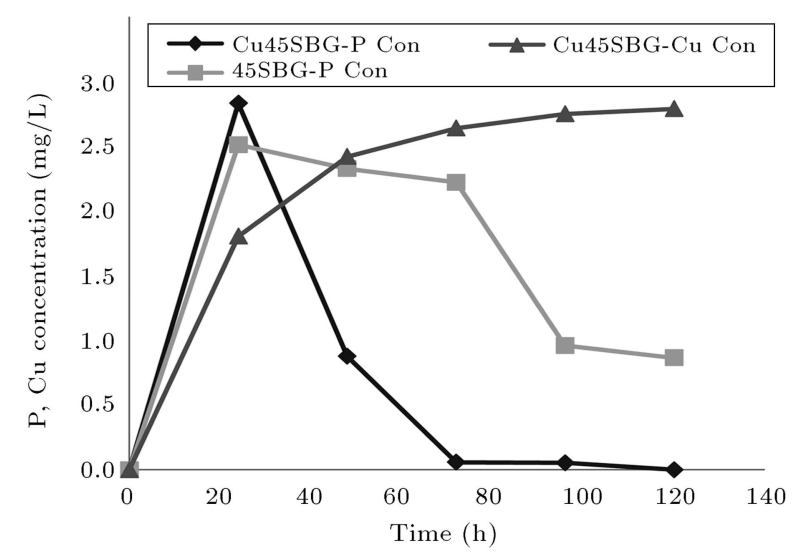

(b)

Figure 13. The dissolution kinetics of $\mathrm{Ca}, \mathrm{P}$, and $\mathrm{Cu}$ in simulated body fluid (for a period of $0-120 \mathrm{~h}$ ) as determined by ICP analysis.

derived particles. Addition of a specific volume of ethanol to the reaction mixture, due to the lower polarity of ethanol than water, decreases the alkoxides hydrolysis rate and the growth of colloids during the process of polycondensation. Thus, it is led to the reduction of the length of silica chains and BG particles size. A greater volume of ethanol should be applied to solutions containing high concentrations of silica precursors $[1,27]$. The decrease of glass particle size led to increasing the glass active surface area, and this increases the ionic specious release, and ultimately may induce elevated antibacterial activity [28]. The results from ICP analysis showed the considerable reduction of phosphate concentration after $24 \mathrm{~h}$ and the increase of $\mathrm{Ca}$ concentration which are markers for HCA layer precipitation. Indeed, the high-surface area and $\mathrm{CaO}$ content of $\mathrm{BG}$ nanopowders and its fast dissolution kinetics prepared the ideal conditions for HCA layer formation on the BG nanopowders [6,2832]. Balamurugan et al. evaluated in-vitro antibacterial activity of silver-incorporated bioglass (AGBG) in comparison with the ternary sol-gel glass (BG) on Escherichia coli bacterium. According to this research, the silver-free BG system had no effect on bacterial growth or viability. But, the AGBG system showed both bactericidal and bacteriostatic actions on a microorganism test. They concluded that the antibacterial effect of the AGBG can be attributed to $\mathrm{Ag}^{+}$ions released from the BG system [6].

Materials containing copper, such as $\mathrm{CuSO}_{4}$ and $\mathrm{Cu}(\mathrm{OH})_{2}$, are known as inorganic materials [33]. Generally, the electrical charge of bacterial cell wall is negative which is due to the presence of carboxylic groups in the lipoproteins at the bacterial surface [34]. Due to the opposite charge between bacteria and released copper ions from nanopowders, bioactivity and adhesion took place between them, and by destroying the cell wall of bacteria, bacterial death occurred [35]. It seems that the mechanism of bactericidal effect of copper nanopowders is related to the $\mathrm{Cu}^{2+}$ ions released from the nanopowders. These ions with positive charge are attracted to the negatively charged bacterial cell wall and by entering into the cells, they inflict damage on the cell wall or make changes in enzyme function or create holes in the cell wall $[23,34]$. Overall, studies have shown that nanopowders have the capability to penetrate into the bacteria. It may be owing to some morphological changes in that cell membrane that causes intracellular material leakage and bacterial death [34,35]. Studies have also shown that the bactericidal effect of metallic nanopowders is driven by their small-sized particle and high surfaceto-volume ratio [3]. It is found that nanopowders have a powerful antibacterial action irrespective of gram classes, though they are more effective against gramnegative than gram-positive bacteria [36]. As shown in Figure 7 , both BG nanopowders had almost the same bactericidal activity on $E$. coli bacterium. But, $\mathrm{Cu} 45$ SBG showed more antibacterial effect on $S$. aureus than 45 SBG nanopowders. These differences between the antibacterial activities of nanopowders on grampositive and gram-negative bacteria could be described by their different membrane structures. Peptidoglycan is a key component of the membrane that causes structural differences in the membrane. Gram-positive bacteria have no outer membrane, but they have a thick peptidoglycan layer at their outermost layer. In comparison, gram-negative bacteria have the much thinner peptidoglycan layer between the cytoplasmic membrane and the outer membrane. Therefore, in order to attain the same influence as $E$. coli, $S$. aureus needs to have a longer contact time or higher catalyst concentrations $[3,36]$.

BG nanopowders usually release ionic compounds over time involving calcium, silicate, and phosphate in the culture medium. This release raises the $\mathrm{pH}$ level of the medium and environment osmotic pressure. These factors are effective in the antibacterial activity of BGs $[1,20,28]$. The chemical composition of BGs and the dissolution condition of their surroundings 
influence the antibacterial effect of them [1]. Mehdi khani Nahrkhalaji et al. [1] showed that 58S (35.09 wt\% $\mathrm{CaO})$ and $63 \mathrm{~S}(28.47 \mathrm{wt} \% \mathrm{CaO}) \mathrm{BG}$ nanopowders displayed good antibacterial effects even at concentrations less than the ones used in clinical applications. The results of the current study specified that nanopowders show great antibacterial effect at concentrations above $12.5 \mathrm{mg} / \mathrm{ml}$ of broth on $E$. coli bacterium. On grampositive bacterium, Cu45SBG nanopowders exhibit a more efficient antibacterial activity than 45SBG nanopowders. The $\mathrm{pH}$ results demonstrated that the $\mathrm{pH}$ value of broth containing nanopowders was always greater than the control sample and rose to nearly 12 . The $\mathrm{pH}$ value of culture medium containing $\mathrm{Cu} 45 \mathrm{SBG}$ nanopowders was less than those containing 45SBG nanopowders. As a matter of fact, the silica concentration of a solution determined the solution basicity. A series of chemical acid-base equilibriums are affected by the $\mathrm{pH}$ of the solution. Some of these equilibriums involve successive de/re protonation of silica ion series such as $\left(\mathrm{SiO}_{4}\right)^{3},\left(\mathrm{HSiO}_{4}\right)^{3}$, and $\left(\mathrm{H}_{2} \mathrm{SiO}_{4}\right)^{2}$ [1,28]. For these compounds, the dissolution of $\mathrm{SiO}_{2}$ leads to the $\mathrm{pH}$ decrease of the medium. In addition, the reaction of $\mathrm{CaO}$ with $\mathrm{H}_{2} \mathrm{O}$ increases the $\mathrm{pH}$ level of the medium which is controlled by the counterbalance of these reactions. The high $\mathrm{SiO}_{2}$ content of $\mathrm{Cu} 45 \mathrm{SBG}$ leading to the increase of silica is released in the broth and decreases the $\mathrm{pH}$ level of the medium. Decreasing $\mathrm{pH}$ level leads to the increase of its degradation rate, resulting in a more calcium release in medium. For 45SBG nanopowders, its lower silica content leads to a higher pH level of the medium (Figures 8 and 10-13).

Previous studies showed that cytotoxicity effects of $\mathrm{Cu}$ and other metallic ions doped bioactive glasses depend on cell type, culture time, and ions dose $[37,38]$. After 24 hours, Cu45SBG nanopowders showed release of $80.25 \mathrm{mg} . \mathrm{L}^{-1}$ for $\mathrm{Cu}$ in culture medium. For copper, a lethal dose (LD50) was reported as $46 \mathrm{mg} \cdot \mathrm{L}^{-1}$ of incubation on mice fibroblasts L929 [37]. Therefore, the selected concentrations of $\mathrm{Cu}$ for incorporating in 45SBG nanopowders must be lower than 1 wt.\% to reach the lower amounts of $\mathrm{Cu}$ concentrations in culture medium. In-vivo studies of bioactive glass particles with different compositions synthesized via sol-gel technique showed that compositions with lower amounts of $\mathrm{SiO}_{2}$ have faster degradation than the ones with higher amounts of $\mathrm{SiO}_{2}$ and more percentage of new bone formed in defects filled with the former [8]. So, bioactive glasses with higher amounts of $\mathrm{SiO}_{2}$ showed that lower degradation could be incorporated into more $\mathrm{Cu}$ concentration according to less $\mathrm{Cu}$ released into them in biological fluids.

\section{Conclusions}

The sol-gel technique was successfully applied to the synthesis of 45SBG and Cu45SBG nanopowders. The size of nanopowders was measured to be around $100 \mathrm{~nm}$. Both nanopowders had no bactericidal effects on $E$. coli and $S$. aureus bacteria at concentrations less than $12.5 \mathrm{mg} / \mathrm{ml}$ of broth. Both BGs showed the similar antibacterial activity on $E$. coli bacteria, and their $\mathrm{MBC}$ was $12.5 \mathrm{mg} / \mathrm{ml}$. In comparison, $\mathrm{Cu} 45 \mathrm{SBG}$ nanopowders with a $\mathrm{MBC}$ of $25 \mathrm{mg} / \mathrm{ml}$ were more effective on $S$. aureus bacteria than $45 \mathrm{SBG}$ with a $\mathrm{MBC}$ of $50 \mathrm{mg} / \mathrm{ml}$. According to these results, a grampositive bacterium ( $S$. aureus) was less susceptible, and it showed higher resistance to the nanopowders than gram-negative bacterium (E. coli). Cu45SBG showed considerable cytotoxic effect on L929 fibroblasts. But, 45SBG demonstrated no cytotoxic effect, especially after 4 and 7 days of incubation. It was concluded that to overcome cytotoxic effect, $\mathrm{Cu}$ content of $\mathrm{BG}$ nanopowders must be lower than the amount used in this research. Therefore, 45SBG nanopowders with dramatic antibacterial activity could be used as a good candidate for dental and orthopedic applications.

\section{Acknowledgements}

The authors acknowledge the financial support for this work by Iran National Science Foundation (INSF, ID: 92034528).

\section{References}

1. Mortazavi, V., Nahrkhalaji, M.M., Fathi, M.H., Mousavi, S.B. and Esfahani, B.N. "Antibacterial effects of sol-gel-derived bioactive glass nanoparticle on aerobic bacteria", J. Biomed. Mater. Res. A., 94(1), pp. 160-168, (2010).

2. Hebert, C.K., Williams, R.E., Levy, R.S. and Barrack, R.L. "Cost of treating an infected total kneereplacement", Clin. Orthop. Rel. Res., 331, pp. 140-145 (1996).

3. Morones, J.R., Elechiguerra, J.L., Camacho, A., Holt, K., Kouri, J.B., Ramirez, J.T. and Yacaman, M.J. "The bactericidal effect of silver nanoparticles", Nanotechnology, 16, pp. 2346-2353 (2005).

4. Ostermann, P.A.W., Henry, S.L. and Seligson, D. "The role of local antibiotic therapy in the management of compound fractures", Clin. Orthop. Rel. Res., 295, pp. 102-111 (1993).

5. Ostermann, P.A.W., Henry, S.L. and Seligson, D. "Timing of wound closure in severe compound fractures", Orthopedics, 17, pp. 397-399 (1994).

6. Balamurugan, A., Balossier, G., Laurent-Maquin, D., Pina, S., Rebelo, A.H.S., Faure, J. and Ferreira, J.M.F. "An in vitro biological and anti-bacterial study on a sol-gel derived silver-incorporated bioglass system", Dent. Mater., 24, pp. 1343-1351 (2008). 
7. Blaker, J.J., Nazhat, S.N. and Boccaccini, A.R. "Development and characterisation of silver-doped bioactive glass coated sutures for tissue engineering and wound healing applications", Biomaterials, 24, pp. 1319-1329 (2004).

8. Hench, L.L. "Bioceramics", J. Am. Ceram. Soc., 81, pp. 1705-1728 (1998).

9. Kokubo, T. "Novel bioactive materials", An. Quim. Int. Ed., 93, pp. S49-S55 (1997).

10. Rahaman Mohamed, N., Day Delbert, E., Sonny Bal, B., Fu, Q., Jung Steven, B., Bonewald Lynda, F. and Tomsia Antoni, P. "Bioactive glass in tissue engineering", Acta. Biomater., 7, pp. 2355-2373 (2011).

11. Fathi, M.H. and Doostmohammadi, A. "Preparation and characterization of sol-gel bioactive glass coating for improvement of biocompatibility of human body implant", Mater. Eng. A., 474, pp. 128-133 (2008).

12. Fathi, M.H. and Doostmohammadi, A. "Bioactive glass nanopowder and bioglass coating forbiocompatibility improvement of metallic implant", J. Mater. Process. Tech., 209, pp. 1385-1391 (2009).

13. Hild, N., Tawakoli Pune, N., Halter Jonas, G., Bärbel, S., Wolfgang, B., Stark Wendelin, J. and Mohn, D. "pH-dependent antibacterial effects on oral microorganisms through pure PLGA implants and composites with nanosized bioactive glass", Acta. Biomater., 9, pp. 9118-9125 (2013).

14. Ping Fan, J., Kalia, P., Di Silvio, L. and Huang, J. "In vitro response of human osteoblasts to multi-step sol-gel derived bioactive glass nanoparticles for bone tissue engineering", Mater. Sci. Eng. C., 36, pp. 206214 (2014).

15. Xin, F., Jian, CH., Jianming, R., Zhongcheng, ZH. and Jianpeng, Z. "Synthesis and degradation properties of $\beta$-TCP/BG porous composite materials", Bull. Mater. Sci., 34(2), pp. 357-364 (2011).

16. Doostmohammadi, A., Monshi, A., Salehi, R., Fathi, M.H., Golniya, Z. and Daniels Alma., U. "Bioactive glass nanoparticles with negative zeta potential", $\mathrm{Ce}$ ram. Int., 37, pp. 2311- 2316 (2011).

17. JonesJulian, R. "Review of bioactive glass: From Hench to hybrids", Acta. Biomater., 9, pp. 4457-4486 (2013).

18. Stoor, P., Soderling, E. and Salonen, J.I. "Antibacterial effects of a bioactive glass paste on oral microorganisms", Acta. Odontol. Scand., 56, pp. 161-165 (1998).

19. Allan, I., Newman, H. and Wilson, M. "Antibacterial activity of particulate Bioglasŝagainstsupra- and subgingival bacteria", Biomaterials, 22, pp. 1683-1687 (2001).

20. Munukka, E., Lepparanta, O., Korkeamaki, M., et al. "Bactericidal effects of bioactive glasses on clinically important aerobic bacteria", J. Mater. Sci. Mater. Med., 19, pp. 27-32 (2008).
21. Baghbani, F., Moztarzadeh, F., Hajibaki, L. and Mozafari, M. "Synthesis, characterization and evaluation of bioactivity and antibacterial activity of Quinary glass system $\left(\mathrm{SiO}_{2}-\mathrm{CaO}-\mathrm{P}_{2} \mathrm{O}_{5}-\mathrm{MgO}-\mathrm{ZnO}\right)$ : In vitro study", Bull. Mater. Sci., 36(7), pp. 1339-1346 (2013).

22. Ren, G., Hu, D., Cheng, E.W.C., Vargas-Reus, M.A., Reip, P. and Allaker, R.P. "Characterisation of copper oxide nanoparticles for antimicrobial applications", Int. J. Antimicrob. Ag., 33, pp. 587-590 (2009).

23. Ruparelia, J.P., Chatterjee, A.K., Duttagupta, S.P. and Mukherji, S. "Strain specificity in antimicrobial activity of silver and copper nanoparticles", Acta. Biomater., 4, pp. 707-716 (2008).

24. Hamouda, I.M. "Current perspectives of nanoparticles in medical and dental biomaterials", J. Biomed. Res., 26, pp. 143-151 (2012).

25. Blanc, D.S., Carrara, P., Zanetti, G. and Francioli, P. "Water disinfection with ozone, copper and silver iones and temperature increase to control Legionella: seven years of experience in a university teaching hospital", J. Hosp. Infect., 60, pp. 69-72 (2005).

26. Matsumoto, N., Sato, K., Yoshida, K., Hashimoto, K. and Toda, Y. "Preparation and characterization of $\beta$ tricalcium phosphate co-doped with monovalent and divalent antibacterial metal ions", Acta. Biomater., 5, pp. 3157-3164 (2009).

27. Hench, L.L. and West, J.K. "The sol-gel process", Chem. Rev., 90, pp. 33-72 (1990).

28. Waltimo, T., Brunner, T.J., Vollenweider, M., Stark, W.J. and Zehnder, M. "Antimicrobial effect of nanometric bioactive glass 45S5", J. Dent. Res., 86, pp. 754-757 (2007).

29. Pereira, M.M., Clark, A.E. and Hench, L.L."Effect of texture on the rate of hydroxyapatite formation on silica gel surface", J. Am. Ceram. Soc., 78, pp. 24632468 (1995).

30. Pereira, M.M., Clark, A.E. and Hench, L.L. "Calcium phosphate formation on sol-gel-derived bioactive glasses in vitro", J. Biomed. Mater. Res., 28, pp. 693698 (1994).

31. Filgueiras, M.R., Latorre, G.P. and Hench, L.L. "Solution effects on the surface reaction of a bioactive glass", J. Biomed. Mater. Res., 27, pp. 445-453 (1993).

32. Saravanapavan, P., Gough, J.E., Jones, J.R. and Hench, L.L. "Antimicrobial macroporous gel glasses: dissolution and cytotoxicity", Key. Eng. Mater., 254256, pp. 1087-1090 (2004).

33. Hughes, M.N. and Poole, R.K., Metals and Microorganisms, London, UK, Chapman and Hall Publications (1989).

34. Stoimenov, P.K., Klinger, R.L., Marchin, G.L. and Klabunde, K.J. "Metal oxide nanoparticles as bactericidal agents", Langmuir., 18, pp. 6679-6686 (2002).

35. Raffi, M., Mehrwan, S., Bhatti, T.M., Akhter, J.I., Hameed, A., Yawar, W. and ul Hasan, M.M. "Investigations into the antibacterial behavior of copper 
nanoparticles against Escherichia coli", Ann. Microbiol., 60, pp. 75-80 (2010).

36. Talebian, N. and Zare, E. "Structure and antibacterialpropertyofnano- $\mathrm{SiO}_{2}$ supported oxideceramic", Ceram. Int., 40, pp. 281-287 (2014).

37. Cao, B., Zheng, Y., Xi, T., et al. "Concentrationdependent cytotoxicity of copper ions on mouse fibroblasts in vitro: effects of copper ion release from TCu380A vs TCu220C intra-uterine devices", Biomed. Micro Devices, 14, pp. 709-720 (2012).

38. Lodemann, U., Einspanier, R., Scharfen, F., Martens, H. and Bondzio, A. "Effects of zinc on epithelial barrier properties and viability in a human and a porcine intestinal cell culture model", Toxicol. In vitro, 27, pp. 834-843 (2013).

\section{Biographies}

Shiva Soltani-Dehnavi holds a Master's degree in Biomedical Engineering (Biomaterial) at Department of New Science and Technology Campus (Biomaterial Group), Semnan University, with research background in antibacterial activity of nanoparticles, guided tissue/bone regeneration, bone/cardiac tissue engineering, cytotoxicity evaluation of biomaterials, and knowledge of biomaterials characterization techniques. She now is enthusiastic about pursuing higher education toward a $\mathrm{PhD}$ degree.

Mehdi Mehdikhani-Nahrkhalaji (PhD, Biomaterials) is now an Assistant Professor of Biomaterials, Department of Biomedical Engineering, Faculty of Engineering, University of Isfahan, Iran. He received his BSc in Materials Engineering, MSc in Corrosion Engineering, and PhD in Biomaterials at Isfahan University of Technology. Currently, Dr. MehdikhaniNahrkhalaji's research studies focus on designing and fabricating of scaffolds and hydrogels containing desired drugs loaded nanoparticles for cartilage, bone, cardiovascular, and skin tissue engineering.

Mohammad Rafienia, PhD, an Associate Professor, received his BSc degree in Materials Engineering from Isfahan University of Technology, Isfahan, Iran, MSc and $\mathrm{PhD}$ degrees from Amirkabir University of Technology, Tehran, Iran, in 2001 and 2007, respectively. Since 2007, he joined Isfahan University of Medical Sciences. Dr. Rafienia's research has focused on designing and fabricating scaffolds for cartilage and bone tissue engineering, investigating the influence of new biomedical nanocomposites on behavior of mesenchymal stem cells and controlled drug delivery.

Ali Doostmohammadi (PhD, Biomaterials) is now an Assistant Professor of Biomaterials, Head of the Materials Department of the Shahrekord University, and Member of the International Ceramic Engineers Association. He received his BSc in Materials Engineering, $\mathrm{MSc}$ in Corrosion Engineering, and $\mathrm{PhD}$ in Biomaterials at Isfahan University of Technology. Currently, Dr. Doostmohammadi's research studies focus on the bioactive ceramics and composites scaffold for bone tissue engineering. He has studied and published papers on the synthesis of novel bioceramics and led his group to achieve applicable results in Tissue Engineering. 